\section{Abstract}

4

\title{
Environmental performance of off-site constructed facilities: A critical review
}

During the recent decades, off-site construction (OSC) has gained a rapid growth worldwide. It has been reported that OSC, as an alternative construction method, has a variety of benefits. However, there is lack of critical review of the building performance (e.g. energy consumption and carbon emissions) of off-site built facilities. Life cycle approach and bibliometric analysis are adopted in this study to review existing research on the environmental performance of off-site built facilities. The results show that most existing studies chose to employ LCA method to systematically analyse carbon emissions and energy consumption of prefabricated residential buildings by using sub-assembly components as functional units. The detailed investigation of volumetric construction and building operational stage are rare. The sensitivity of thermal property caused by offsite manufacturing and onsite assembly in comparison to the traditional cast-in-situ method remains unexplored. It is encouraged to cover various environmental impacts in building performance assessment, to develop a sustainability rating system applied in OSC, to adopt Internet-of-Things in OSC monitoring by using real-time data, and to establish an indicator system for the evaluation of OSC performance. The findings of this study can facilitate the understanding of status quo and shed lights on future research direction in OSC.

Keywords: Off-site construction; life cycle approach; energy consumption; carbon emissions; environmental performance

\section{Introduction}

Building-related energy issues have attracted global attention. According to International Energy Agency [1], the building sector contributes to approximately $40 \%$ of global primary energy consumption, with more severe situation in the developed and urbanized countries [1]. 
27 Energy consumption of buildings covers not only material usage and construction equipment input, but also the operation and maintenance process. In general, electricity and natural gas used for operating a building are estimated to account for more than $80 \%$ of buildings' total energy consumption throughout the entire life cycle. With the consistent emphasis on green technology and high-standard liveability, the role of embodied energy becomes increasingly important. Embodied energy covers energy consumed during raw material production, transportation, and onsite construction process. As a result, the erection and usage of a building is responsible for significant environmental issues, such as resource depletion and greenhouse gas emission.

To tackle these problems, some strategies have been adopted to mitigate adverse environmental loading and to improve construction efficiency in construction projects. Offsite construction (OSC) offers a new approach by producing building components in an offsite manufacturing factory, transporting the complete or semi-complete prefabricated products (i.e., components) into the jobsite, and finally assembling these components to construct buildings [2]. A few interchangeable terms for OSC have been used in the literature [3], such as prefabricated construction or modular construction. According to Hong, Shen, Li, Zhang and Zhang [4] and Gibb [5], there are mainly four categories of OSC, namely: (1) component manufacturing and subassembly; (2) non-volumetric pre-assembly not enclosing usable space; (3) volumetric pre-assembly with usable spaces; and (4) the entire modular buildings that form the actual fabric of a building. In traditional onsite construction, raw building materials are transported and constructed on-site. By contrast, OSC moves the building process from the construction sites into a controlled factory environment [6], thus gaining advantages in cost and time saving $[7,8]$.

The performance of OSC compared to that of traditional cast-in-situ has been an ongoing research theme in the domain of OSC [9]. More specifically, OSC is a time-efficient and 
cost-saving method that achieves the sustainable construction without compromising the building shape and design. Three key objectives (i.e. quality, time, and cost) play crucial roles in project management. From a managerial perspective, the physical quality control [10], schedule flexibility $[11,12]$, and economic benefits of OSC $[7,13,14]$ have been extensively studied from both theoretical and practical perspectives in the past decades. From a resource input perspective, it is necessary to have basic elements (e.g. labour, material, equipment) for building construction. Therefore, the labour demand, material usage, and equipment requirement are comprehensively evaluated in the prefabrication research domain [15-18]. As an emerging technique, the corresponding innovative management methods and changes in stakeholder relationship also attracted attention from the research community [19]. In addition, a vast body of work discussed the co-benefits from the implementation of OSC technique, including waste, noise, and dust reductions [20, 21]. Apart from these advantages, OSC is considered as a modernized construction method that moves towards a greener production [22, 23]. With the rising demand for high-quality development, a growing number of publications put efforts to understand the knowledge of the life-cycle environmental benefits of OSC. The mounting pressure of global climate change abatement also urges policy makers to better understand the net environmental gains by adopting the OSC technique. Therefore, it is imperative to conduct a critical review of existing studies related to environmental performance of OSC, particularly for energy consumption and carbon emission, which are the major driving factors leading to climate change. This review-based study extends previous scholarly work in OSC (e.g.,Jin, Gao, Cheshmehzangi and Aboagye-Nimo [9]) by targeting the critical issue of environmental performance of OSC especially in the post-construction stages. It addresses the need for a critical evaluation of OSC from the life cycle perspective. It targets three research questions in the environmental evaluation-based studies in the OSC domain related to: (1) what is the 
main research scope in light of the environmental performance of off-site built facilities (e.g., volumetric verse sub-assembly; simulation verse real-time monitoring)? (2) what are the limitations of these existing studies? and (3) what are the potential directions of future research? Overall, this study contributes to the body of knowledge in OSC both practically and theoretically. Practically, the understanding of OSC from an environmental perspective can facilitate decision making to mitigate environmental burdens from the accelerated urbanization in the current construction practice. Theoretically, identifying the hotspots and burgeoning issues in OSC is beneficial for the future research.

The following sections are arranged as: Section 2 describes the methodology to undertake this review; Section 3 presents the quantitative review results; Section 4 provides an in-depth qualitative discussion to address the two of the aforementioned research questions related to the mainstream research topics and limitations of existing studies; Section 5 proposes the future research agenda and framework; and Section 6 concludes this study.

\section{Research method}

92 Main databases (i.e. Web of Science and Scopus) were used to locate literature related to OSC. This is followed by a critical review of related literature. The workflow for the bibliometric search of literature related to the building performance of off-site built facilities

95 is described in Fig.1. 


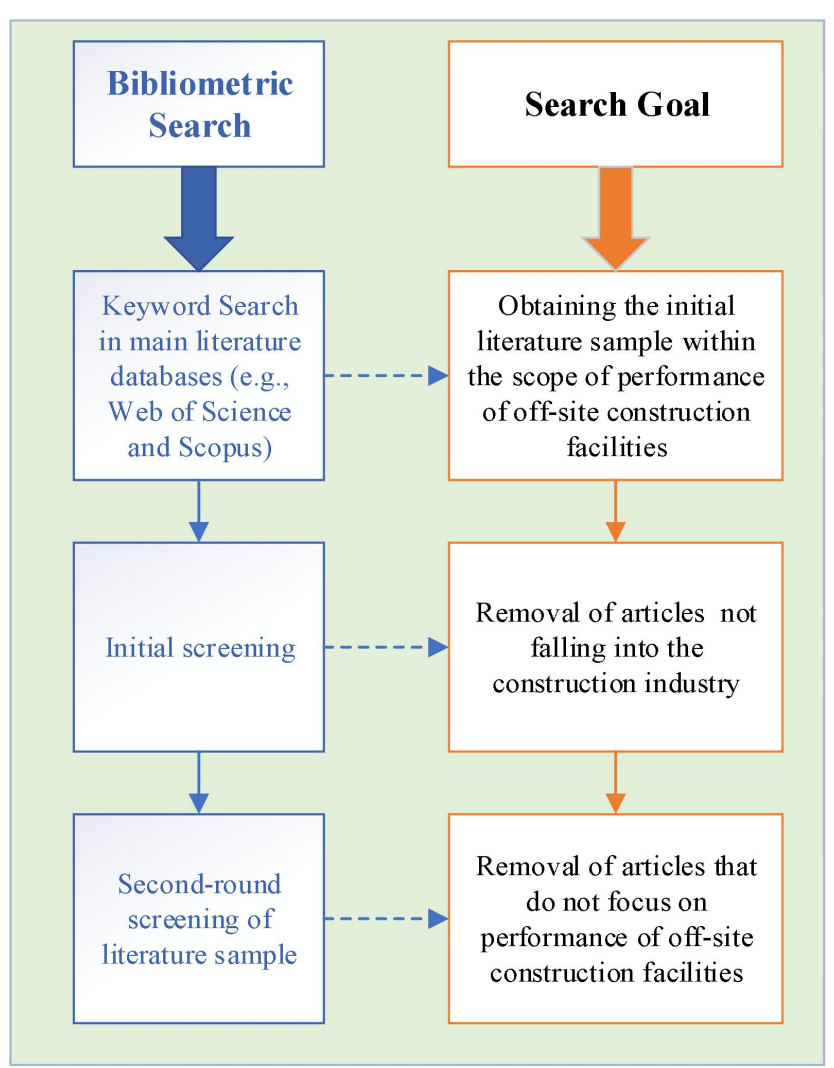

Fig.1. Bibliometric search of literature related to building performance of off-site built facilities

\subsection{Keywords}

Keywords used to search academic databases followed the format described in Table 1. It can be observed in Table 1 that there are two main categories of keywords (i.e., OSC and building performance) that the existing studies have attempted to address. Keywords within each category are based on a "OR" relationship, meaning that the literature only need to contain one of the keywords listed under each category. The "AND" logical relationship is used to link the two categories to screen literature that target both categories.

Table 1. Keyword selection for bibliometric search of literature

\begin{tabular}{|c|c|}
\hline Keyword related to OSC & $\begin{array}{l}\text { Keyword related to building performance } \\
\text { measurements }\end{array}$ \\
\hline $\begin{array}{l}\text { "Off-site construction" OR "offsite construction" OR } \\
\text { "prefabricated construction" OR "industrialized } \\
\text { building" OR "panelized construction" OR "modular } \\
\text { construction" OR "tilt up construction" OR "offsite } \\
\text { construction" OR "precast construction" }\end{array}$ & $\begin{array}{l}\text { "Carbon emissions" OR "greenhouse gas" OR "Energy } \\
\text { performance" OR "Energy consumption" OR "Carbon } \\
\text { footprint" OR "Building performance" OR "Embodied } \\
\text { Energy" OR "Operational energy" OR "energy input" }\end{array}$ \\
\hline
\end{tabular}


Only literature published in English was selected as the sample for the follow-up analysis. The type of literature included was not limited to journal articles but might also include conference proceedings, due to the fact that the research on building performance for off-site built facilities might still be in its early stage.

\subsection{Screening process}

113 Following the workflow described in Fig.1, the abstracts of the initially selected literature were reviewed in order to weed out the literature (e.g.,Nagy and Hajrizi [24]) which did not focus on OSC in the construction. Following the initial screening of literature, the secondary screening aimed to exclude the remaining literature that did not focus on the energy consumption or carbon emissions of off-site built facilities. For example, despite focusing on the energy saving potential for industrialized building in its retrofitting stage, Wang and Martinac [25] did not highlight the difference between industrialized building and traditional cast-in-situ facilities, but mainly on retrofitting strategies. Other studies such as Zhang, Long, Lv and Xiang [26], although with focuses on OSC or modular construction, did not examine the environmental performance of OSC. In the second round of screening, these types of literature were further excluded from the final literature sample.

\subsection{Review methods}

After finalizing the literature sample targeting on the energy consumption or carbon emissions, the further review method should be determined, depending on the sample size. Generally, with a larger sample of literature (e.g., over 100), a text-mining-based approach has been gaining a wider application to assist the review of a certain domain. Examples can be found in adopting the science mapping approach in the domain of construction safety [27] and public-private-partnership [28]. With a limited sample of papers in the given research topic, i.e., the environmental performance of off-site built facilities in this study, a content analysis provides an effective approach to conduct a further in-depth discussion. 
133 Content analysis is a systematic and replicable technique to compress a large amount of texts 134 into categorized contents based on certain explicit rules of coding [29, 30]. It enables researchers to sift through a large volume of data with relative ease in a systematic approach [31]. Content analysis is a useful tool to examine trends and patterns in documents [32], such as the mainstream research methodology adopted to investigate the building performance of off-site built facilities in comparison to that of cast-in-situ facilities. The steps and relevant details of conducting content analysis in reviewing a relatively large sample of documents can be found in existing studies such as Bogus, Migliaccio and Jin [33].

\section{Results}

\subsection{Overall literature sample}

Initially a total of 148 papers were located following the searching strategy described in 2.1 . Finally, a total of 43 papers were selected to undertake the content analysis. Almost all these studies were published within the recent decade, with most of them published within the recent five years. This indicates that the building performance of off-site built facilities is becoming an emerging research topic. A recent literature review of OSC [9] showed that 349 OSC-based journal articles were published in the last decade. By contrast, the number of studies on the building performance of off-site built facilities only accounts for a relatively small portion. Table 2 lists a few typical examples of studies that investigate the building performance between OSC and cast-in-situ facilities.

Table 2. Examples of studies on the environmental performance of off-site built facilities

\begin{tabular}{|l|l|l|l|l|l|}
\hline Study & $\begin{array}{l}\text { Level of } \\
\text { prefabrication }\end{array}$ & $\begin{array}{l}\text { Type of } \\
\text { building }\end{array}$ & $\begin{array}{l}\text { Building } \\
\text { performance } \\
\text { studied }\end{array}$ & Methodology & Major findings \\
\hline
\end{tabular}




\begin{tabular}{|c|c|c|c|c|c|}
\hline $\begin{array}{l}\text { Jeong, } \\
\text { Hong, Ji, } \\
\text { Kim, Lee, } \\
\text { Jeong and } \\
\text { Lee [34] }\end{array}$ & $\begin{array}{l}\text { Precast } \\
\text { concrete } \\
\text { component } \\
\text { named LPSRC } \\
\text { column }\end{array}$ & $\begin{array}{l}\text { Factory } \\
\text { project }\end{array}$ & $\begin{array}{l}\text { Carbon } \\
\text { emission }\end{array}$ & $\begin{array}{l}\text { Two case study } \\
\text { projects, Web- } \\
\text { CYCLONE } \\
\text { simulation and } \\
\text { equation-based } \\
\text { methods }\end{array}$ & $\begin{array}{l}\text { The alternative precast } \\
\text { column improved project } \\
\text { productivity and achieved } \\
\text { cost saving, but the } \mathrm{CO}_{2} \\
\text { emission of the precast } \\
\text { column was } 72 \% \text { higher. }\end{array}$ \\
\hline $\begin{array}{l}\text { Kosir, } \\
\text { Iglic and } \\
\text { Kunic [35] }\end{array}$ & $\begin{array}{l}\text { Volumetric } \\
\text { unit }\end{array}$ & $\begin{array}{l}\text { Singular } \\
\text { prefabricated } \\
\text { modular } \\
\text { container } \\
\text { unit, and } \\
\text { multi-unit } \\
\text { modular } \\
\text { office } \\
\text { building }\end{array}$ & $\begin{array}{l}\text { Heating, } \\
\text { cooling and } \\
\text { lighting } \\
\text { energy } \\
\text { performance, } \\
\text { and daylight } \\
\text { efficiency }\end{array}$ & $\begin{array}{l}\text { Modelling and } \\
\text { simulation } \\
\text { according to } \\
\text { the } \\
\text { specifications } \\
\text { of Slovenian } \\
\text { modular unit } \\
\text { manufacturer }\end{array}$ & $\begin{array}{l}\text { The operational energy } \\
\text { could be successfully } \\
\text { reduced if the right } \\
\text { design measures are } \\
\text { incorporated on the level } \\
\text { of envelope design. } \\
\text { Singular modular units } \\
\text { could serve as a basic } \\
\text { design guideline. }\end{array}$ \\
\hline $\begin{array}{l}\text { Li, Lu, } \\
\text { Wang, } \\
\text { Huang, } \\
\text { Chen and } \\
\text { Wang [22] }\end{array}$ & $\begin{array}{l}\text { Modular } \\
\text { building }\end{array}$ & $\begin{array}{l}\text { Modular } \\
\text { prefabricated } \\
\text { steel } \\
\text { structure } \\
\text { building for } \\
\text { experimental } \\
\text { study }\end{array}$ & $\begin{array}{l}\text { Thermal } \\
\text { performance, } \\
\text { building } \\
\text { performance } \\
\text { in terms of } \\
\text { sustainability, } \\
\text { climate } \\
\text { adaptability }\end{array}$ & $\begin{array}{l}\text { Full-scale } \\
\text { building model } \\
\text { constructed for } \\
\text { feasibility } \\
\text { study of } \\
\text { construction } \\
\text { details } \\
\text { followed by } \\
\text { computer } \\
\text { simulation }\end{array}$ & $\begin{array}{l}\text { The two materials (i.e., } \\
\text { high insulation panels } \\
\text { and aerogel blankets) } \\
\text { adopted in modular } \\
\text { prefabricated buildings } \\
\text { demonstrated significant } \\
\text { energy savings superior } \\
\text { than the current national } \\
\text { standard. }\end{array}$ \\
\hline $\begin{array}{l}\text { Lim et al. } \\
\text { (2017) }\end{array}$ & $\begin{array}{l}\text { IBS (i.e., } \\
\text { Industrialized } \\
\text { building } \\
\text { system) } \\
\text { components: } \\
\text { precast } \\
\text { concrete }\end{array}$ & $\begin{array}{l}\text { Residential } \\
\text { building }\end{array}$ & $\begin{array}{l}\text { Carbon } \\
\text { footprint }\end{array}$ & $\begin{array}{l}\text { Life Cycle } \\
\text { Assessment to } \\
\text { a case study } \\
\text { residential } \\
\text { building }\end{array}$ & $\begin{array}{l}\text { The amount of carbon } \\
\text { footprint can be } \\
\text { minimized by replacing } \\
\text { the raw materials used } \\
\text { partly or entirely with } \\
\text { materials with lower } \\
\text { embodied energy. }\end{array}$ \\
\hline $\begin{array}{l}\text { Teng, } \mathrm{Li}, \\
\text { Pan and } \\
\mathrm{Ng}[36]\end{array}$ & Not specified & $\begin{array}{l}27 \quad \text { cases } \\
\text { with mostly } \\
\text { residential } \\
\text { buildings }\end{array}$ & $\begin{array}{l}\text { Embodied and } \\
\text { operational }\end{array}$ & $\begin{array}{l}\text { Literature } \\
\text { review }\end{array}$ & $\begin{array}{l}\text { On average, } 15.6 \% \text { of } \\
\text { embodied and } 3.2 \% \text { of } \\
\text { operational carbon } \\
\text { reductions were achieved } \\
\text { through prefabrication, as } \\
\text { compared with their } \\
\text { traditional base cases. }\end{array}$ \\
\hline $\begin{array}{lr}\text { Tao, } & \text { Mao, } \\
\text { Xie, } & \text { Liu } \\
\text { and } & \text { Xu } \\
{[37]} & \end{array}$ & $\begin{array}{l}\text { Component for } \\
\text { subassembly }\end{array}$ & $\mathrm{N} / \mathrm{A}^{1}$ & $\begin{array}{l}\text { Greenhouse } \\
\text { gas emission } \\
\text { during the } \\
\text { manufacturing } \\
\text { stage }\end{array}$ & $\begin{array}{l}\text { Real time } \\
\text { monitoring of } \\
\text { greenhouse gas } \\
\text { emission the } \\
\text { during the } \\
\text { manufacturing } \\
\text { stage using an } \\
\text { Internet-of- } \\
\text { Thing (IoT) } \\
\text { approach } \\
\end{array}$ & $\begin{array}{l}\text { The implementation of } \\
\text { the IoT-based monitoring } \\
\text { system in production line } \\
\text { demonstrated its } \\
\text { capability to allow timely } \\
\text { monitoring and control of } \\
\text { carbon emissions. }\end{array}$ \\
\hline $\begin{array}{l}\text { Tumminia, } \\
\text { Guarino, } \\
\text { Longo, }\end{array}$ & $\begin{array}{l}\text { Whole } \\
\text { modular } \\
\text { building }\end{array}$ & $\begin{array}{l}\text { Office } \\
\text { building } \\
\text { using solar }\end{array}$ & $\begin{array}{l}\text { Energy } \\
\text { performance } \\
\text { and }\end{array}$ & $\begin{array}{l}\text { Case study } \\
\text { using life cycle } \\
\text { assessment }\end{array}$ & $\begin{array}{l}\text { The material production } \\
\text { stage was found with the } \\
\text { highest impact on }\end{array}$ \\
\hline
\end{tabular}




\begin{tabular}{|c|c|c|c|c|c|}
\hline $\begin{array}{l}\text { Ferraro, } \\
\text { Cellura } \\
\text { and } \\
\text { Antonucci } \\
{[38]}\end{array}$ & & $\begin{array}{l}\text { as the main } \\
\text { renewable } \\
\text { energy } \\
\text { source }\end{array}$ & $\begin{array}{l}\text { environmental } \\
\text { impacts }\end{array}$ & $\begin{array}{l}\text { based on a } \\
\text { combination of } \\
\text { site monitoring } \\
\text { and dynamic } \\
\text { simulation }\end{array}$ & $\begin{array}{l}\text { building energy } \\
\text { performance. In contrast, } \\
\text { the operation stage only } \\
\text { accounted for } 23 \% \text { of the } \\
\text { total life cycle impacts,. }\end{array}$ \\
\hline $\begin{array}{l}\text { Wen, } \\
\text { Siong and } \\
\text { Noor [39] }\end{array}$ & $\begin{array}{l}\text { Prefabricated } \\
\text { components }\end{array}$ & $\begin{array}{l}\text { Residential } \\
\text { apartments }\end{array}$ & $\begin{array}{l}\text { Embodied } \\
\text { energy and } \\
\text { global } \\
\text { warming } \\
\text { potential }\end{array}$ & $\begin{array}{l}\text { Input-output } \\
\text { Life Cycle } \\
\text { Assessment, } \\
\text { simulation in } \\
\text { Gabi software }\end{array}$ & $\begin{array}{l}\text { Compared to the cast-in- } \\
\text { situ residential buildings, } \\
\text { the industrialized } \\
\text { building reduced } \\
\text { embodied energy with a } \\
\text { lower carbon emission. }\end{array}$ \\
\hline
\end{tabular}

1: The study of [37] was based on the carbon footprint of prefabricated component during its manufacturing, and was not studied in the stage of building site construction.

It can be observed in Table 2 that these studies targeted OSC in various levels of prefabrications (e.g., component or volumetric unit), in different building sectors (e.g., residential houses), and used a variety of research methodologies. A further content analysis of the finalized literature sample is illustrated in Fig.2.

\subsection{Content analysis of finalized literature sample}

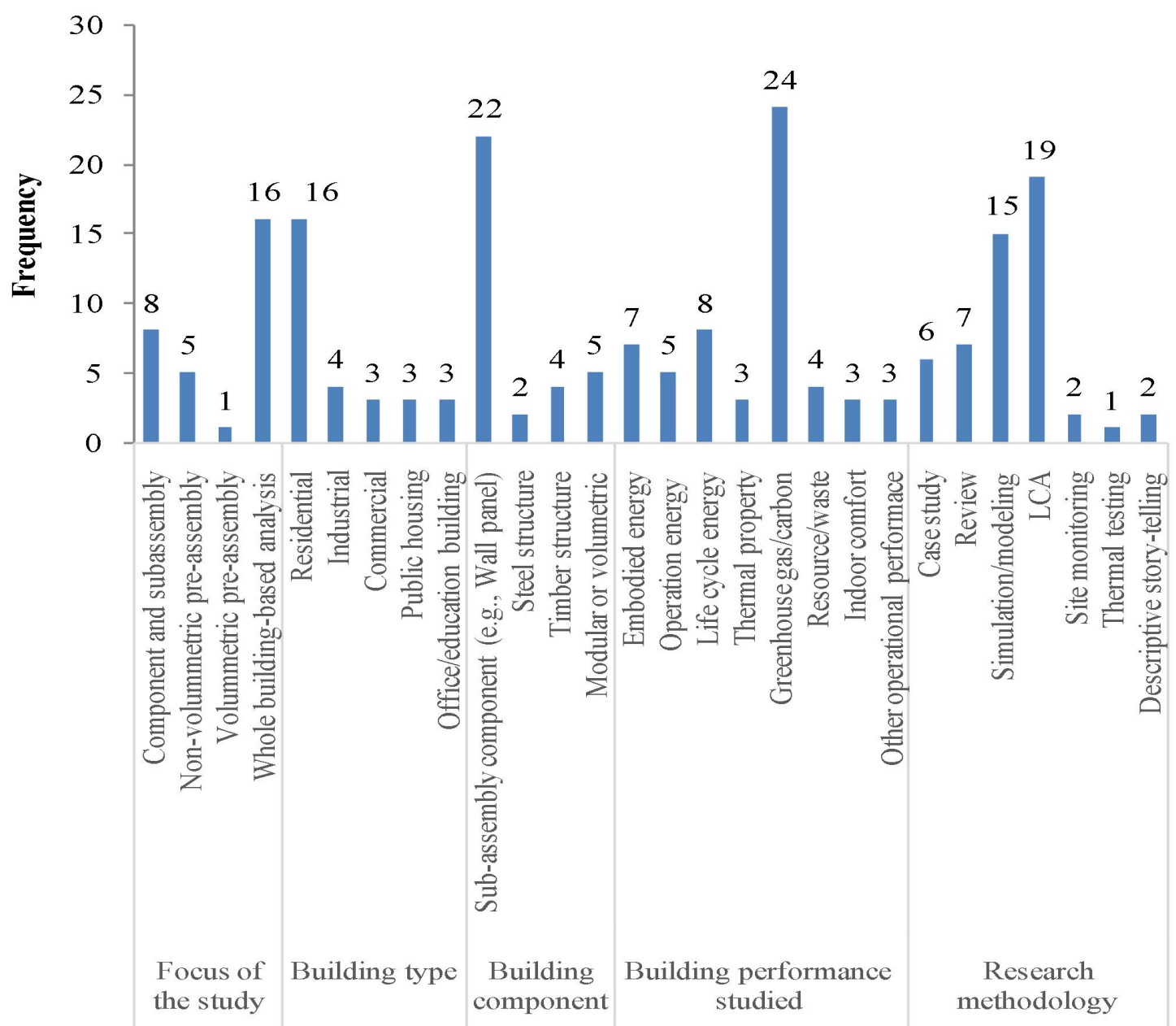


Note: the total number of frequencies within each category may not the total literature sample because one study may cover multiple items within each category. For example, one single research could study both embodied energy and indoor comfort in the category named "Building performance studied".

Fig.2. Content analysis results of the finalized literature sample studying the performance of OSC

Other operational performance examined in the existing studies, as listed in Fig.2, included acoustic constraints, climate adaptability, and health/welling. Fig.2 conveys the information that more studies have targeted the whole building for the performance analysis, although performance studies solely at the component level can also be widely found (e.g.,[40, 41]). It should be noticed that these studies focusing on the whole building analysis may not be based on the modular or volumetric construction. Instead, the scope of performance analysis can be based on the whole building, which may be constructed by sub-assembly components. The category of building component, as shown in Fig.2, summarizes the building element that was adopted as the off-site manufactured components for the performance evaluation. It can be observed that the majority of the studies utilized the sub-assembly (e.g., wall panel, precast column) as the off-site manufactured building component for the performance analysis of OSC. Carbon emission and energy performance are the most common environmental performance aspects that were evaluated in existing studies. The energy performance could be further categorized as embodied energy, operation energy, and energy in the life cycle assessment (LCA). LCA has been the most common research method to examine the performance of off-site built facilities, followed by computer-based simulation and modelling. It should be noticed that these two most widely adopted research methods are not separated, but often integrated. For example, Cao, Li, Zhu and Zhang [42] adopted the Building for Environmental and Economic Sustainability (BEES) as the tool to conduct the LCA for environmental impact of prefabricated building. Chou and Yeh [43] developed the process-based LCA Monte Carlo probability simulation to evaluate the carbon emission and environmental cost of building construction. 


\section{Discussion of mainstream research and limitations}

\subsection{Focuses of mainstream studies}

Results of the content analysis are shown in Fig.2. It can be observed that majority of existing studies have concentrated on the sub-assembly level of OSC in the residential sector, with energy performance and greenhouse/carbon as the mainstream performance indicators. The LCA and simulation are the dominating research methods than the real-time monitoring of off-site built facilities.

\subsubsection{The prefabrication level}

OSC can be categorized into subassembly, non-volumetric pre-assembly, volumetric preassembly, and modular construction according to the extent of prefabrication rate. However, the major focus of environmental performance analysis in the OSC field is still at the subassembly level. This is mainly because sub-assembly construction method can, to some extent, take the superiority of precast construction and maintain building aesthetic values. Hence, it has been more widely applied worldwide. By contrast, volumetric construction is criticized by its lower aesthetic value. Besides, in comparison to a building constructed at a lower prefabrication rate, volumetric construction requires additional coordination and planning work due to its difficulties in logistics and building design process [44]. The high initial cost also impedes the application of volumetric construction because the modules for volumetric construction are built in a more integrated manner with higher completeness [7]. As a result, the applications and studies on OSC with higher prefabrication rates are rare. However, given the importance of modular construction with due consideration of site, labor, and time restrictions, it is urgent to decode the environmental complexity embedded in buildings with higher prefabrication rates.

\subsubsection{Mainstream OSC applications}


217 The superiority of OSC in standardization allows the mass production of buildings by using

218 the standardized drawings and component, and further encourages a widespread application

219 of prefabrication in residential buildings. The reasons that more OSC studies have targeted

220 the residential sector could be partly due to the housing shortages which call for more cost-

221 effective approaches to meet the public needs. Practical examples of OSC approach to meet housing needs can be found worldwide such as UK [45]. The availability of the similar cases in the residential sector motivates more research of evaluating the performance of off-site built residences. On the other hand, the backward development of prefabrication places major challenges for investigating prefabricated buildings with volumetric construction given the barriers of cost and technology. As a result, considerable amount of studies has focused on sub-assembly components. More specifically, given the prefabrication is still in its early stage, local government or developers prefer to control prefabrication rate to seek the balance between advanced technology implementation and building cost [4], thereby minimizing the case of volumetric pre-assembly, especially high-rise volumetric buildings. This is particularly the case for these located in the areas with adverse geological and weather conditions and with high demands on production quality and assembly techniques.

\subsubsection{Mainstream performance indicators}

Data are the core factor affecting the scope, focus, and accuracy of prefabrication-related developers, suppliers, and contractors are unwilling to share detailed inventory data during building construction phase, and that restricts the data accessibility for the public and research committee. Therefore, the case study approach is dominating in prefabrication- 
related studies with process-based LCA as the major underlying method. However, such case-by-case investigation reduces the comparability among different counterparts due to variations in methodological assumption, data source, as well as temporal, geographic, and technical representativeness. Moreover, although precast construction emphasizes the precise production in the off-site manufacturing factory, data collected through the entire supply chain still suffer from different levels of uncertainty. Therefore, in addition to the quantitative simulation, qualitative analysis (e.g., descriptive story-telling) still plays a critical role in prefabrication studies.

The drawbacks in data quality and availability related to OSC performance have caused existing studies largely adopting simulation, LCA, or qualitative studies using cases. These performance indicators are so far largely limited to energy and carbon emission. That could be explained by the facts that: (1) several existing building sustainability rating system such as LEED as shown in U.S. Green Building Council [46] assign more weighting to these two main assessment criteria; (2) These two indicators or assessment criteria can be more easily simulated in existing software tools, such as IES [47]. However, it is worth noting that some other emerging rating systems of building sustainability have drawn a growing level of public attention, e.g., WELL [48]. These emerging rating tools cover a variety of other indicators including indoor health and well-being. Therefore, the performance indicator for off-site built facilities could turn out more comprehensive especially by covering indicators related to 261 human health and well-being.

\subsection{Limitations of existing studies}

The main scope of these existing studies also yield several limitations.

\subsubsection{Limitations in research methods}

Although sufficient studies have been undertaken on specific prefabricated components and their roles in the whole building, the detailed investigation of volumetric construction, 
including volumetric modular and volumetric buildings, is still rare. As highlighted by [37], most previous studies targeting the carbon emissions of construction projects have been limited to emission prediction before construction or quantitative analysis following construction. There have been limited real-time monitoring system to capture the on-time data of building performance. Further extending from the statement of [37], most studies on the performance of off-site built facilities have been based on the LCA approach or computer-based simulation, but with limited work performed to capture the real-time data of building performance. The traditional LCA or simulation approach could generate certain degree of uncertainty, and needs to be validated with real-time data from site monitoring. Lack of actual operational data from existing prefabricated buildings can be found in recent studies (e.g., $[34,49])$. Data source and the corresponding data quality are major barriers to enhance the implications of findings on the performance of OSC projects [50].

Given the high prefabrication rate and large volume of modular units, the volumetric construction exhibits large challenges to the off-site manufacturing, logistic, onsite assembly, operation, and demolition processes in terms of technical and managerial aspects. Therefore, it is suggested to conduct experimental studies to make an in-depth analysis of life cycle environmental performance of this specific prefabrication unit.

\subsubsection{Limitations in building project phases}

Most studies in the prefabrication field concentrate on the building embodied phase, covering the off-site manufacturing, transportation, and onsite assembly processes. However, restricted by the infancy stage of prefabrication, there are few studies on the environmental performance of building operational and demolition phases. More specifically, thermal test needs to be further enhanced to examine the environmental impacts during the operational phase of prefabricated buildings. The sensitivity of thermal property caused by offsite manufacturing and onsite assembly in comparison to the traditional cast-in-situ method 
remains unexplored. Some scholars have targeted in this specific field. Aye, Ngo, Crawford,

293 Gammampila and Mendis [51] demonstrated that there were no obvious energy reduction

294 benefits by using prefabrication techniques during building operation. Zhu, Hong, Shen, Mao,

295 Zhang and $\mathrm{Li}$ [49] considered the advantage of prefabricated buildings in thermal 296 performance improvements from the enhanced air tightness and material substitution. The findings revealed that prefabricated buildings exhibited greener attributes when compared to traditional buildings. In addition, given the large saving potential in the demolition phase of this innovative construction method [52], the lack of case studies on the demolition phase may cause the misinterpretation of life cycle environmental performance of prefabricated buildings.

\subsubsection{Limitations in environmental impact assessment}

Besides carbon emission and energy consumption, other types of environmental impacts, such as global warming, ozone exhausting, and water consumption have not been considered in the industry. 
A critical review of these existing studies indicates that following areas could be further investigated, namely adoption of existing sustainability rating system into OSC, IoT applications in OSC, and a comprehensive indicator system for OSC performance incorporating the Big Data approach.

\subsection{Sustainability rating system applied in OSC}

Sustainability rating systems, including but not limited to LEED [46], BREEAM [53], and Green Star [54], could be adopted for OSC projects in different structural forms (e.g., modular container, timber frame, etc). Although OSC is inherently linked to sustainability [55], existing studies have not paid sufficient attention to the sustainability and lean features from OSC [56]. Furthermore, these sustainability rating systems have not been found widely evaluating the environmental performance. 


\subsection{IoT application in OSC monitoring}

IoT aims to enhance the world connection by enabling the integration of things in both physical world and cyber space [57]. It generates a diversity of datasets assisted by the great number of wireless sensor devices [57]. IoT covers the emerging digital technologies that are being applied in the construction industry, including BIM, virtual reality, and augmented reality, etc. Mao, Tao, Yang, Chen and Liu [58] proposed an IoT-based system framework that could integrate a distributed sensor network to collect real-Time emissions data accompanied a BIM-based virtual model to monitor the emissions status of different construction activities. Tao, Mao, Xie, Liu and Xu [37] moved a step forward to implement the greenhouse gas (GHG) emission monitoring system based on IoT to enable the real-time monitoring of GHG emission during the manufacturing stage of prefabricated components. Application of IoT-based technological system in OSC real-time monitoring is in the early stage, and could be further extended from the pre-construction to operation stages. Latest smart technologies would allow the remote control and monitoring the OSC facilities in an "in-house cloud". These technologies would enable the OSC performance data collection, filtering, analytics, interpretation, and storage for prediction and optimization purposes of future OSC facilities in a similar scenario.

\subsection{An indicator system for the evaluation of OSC performance}

Studying the performance of off-site manufactured buildings has been gaining the momentum in recent years. Practically, stakeholders are concerned of multiple indicators of OSC performance, such as the cost, quality, and post-construction building performance, etc. Existing studies have not been investigating the different performance indicators of OSC, such as energy performance [38], carbon emission [36], and other engineering properties [59]. A comprehensive indicator system to evaluate the building performance of OSC by incorporating cost, energy efficiency, carbon footprint, indoor health and wellbeing, and 
other measurements would be insightful to shed light on the understanding of OSC performance, based on the comparison to the conventional site-built facilities. The structural forms of OSC vary, e.g., timber frame, precast concrete, and modular container. Big Data approach has displayed its potential in construction industry, such as construction waste management $[60,61]$. OSC remains its infancy stages in several developing economies such as China [4]. As a result, the Big Data approach may not be immediately feasible for the performance analysis of OSC projects. Nevertheless, the potential of Big Data in being applied in the OSC performance evaluation through the site monitoring and data collection. The experimental approach of site-built OSC facilities could be one of the research methodologies to analyze the gap between simulation and actual performance that is monitored on-site. In recent years, the emerging "Living Lab" concept [62] could fit the OSC technique by building site building units for academic research and public outreach. The "Living Lab" could also bridge the academia and industry by sharing the building performance data monitored on-site. It also allows the trial of different modular building components that fit into the OSC technique, e.g. off-site built foundation system, wall panels, and green roof panels, etc.

Following the discussion of limitations associated with existing research, a framework is proposed for the future studies (Fig.3). This framework incorporates the sustainability rating, IoT, performance indicator system, and the knowledge base. Amongst these critical components, knowledge base was defined by GhaffarianHoseini, Zhang, Nwadigo, 


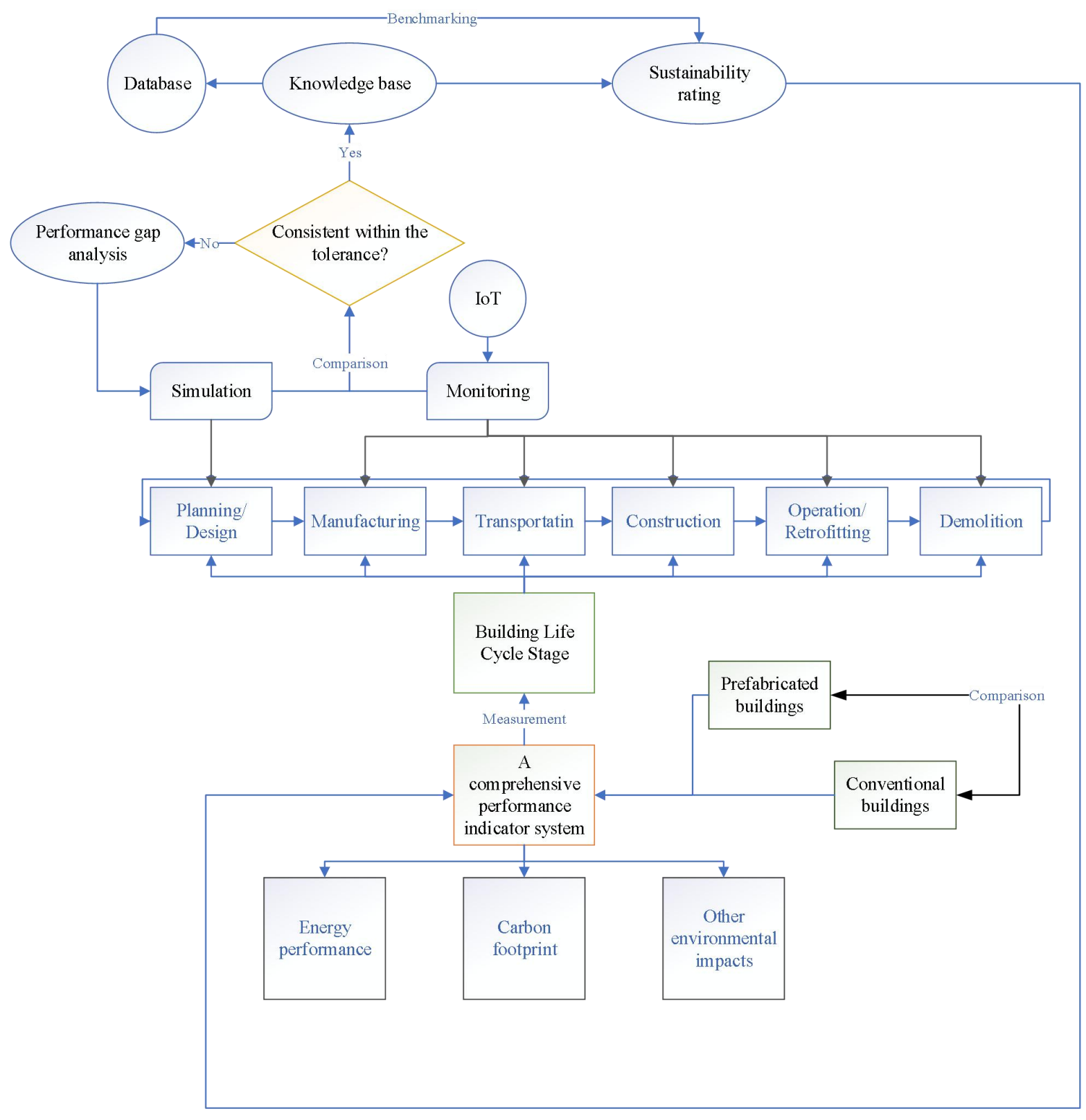

Fig.3. Research framework for continuing the scholarly work of developing the knowledge base for prefabricated buildings

According to GhaffarianHoseini, Zhang, Nwadigo, GhaffarianHoseini, Naismith, Tookey and Raahemifar [63], LCA approach should be adopted to control the energy efficiency especially 394 the post-construction stage which accounts for a high proportion of the total energy consumption. The Integrated Knowledge-based Building Management System adopting multi-dimensional BIM proposed by GhaffarianHoseini, Zhang, Nwadigo, GhaffarianHoseini, 
397 Naismith, Tookey and Raahemifar [63] is for general construction. Such integrated 398 approached could be further extended to the context of prefabricated buildings, meanwhile 399 inheriting the standardized and dynamic features of this system. Existing OSC projects could 400 be adopted as cases to implement the framework of Integrated Knowledge-based Building 401 Management System using nD BIM applications (e.g.[64]), which emphasizes the energy performance of facilities in the post-construction stages.

\section{Conclusions}

Off-site construction has drawn wide attention in last decades due to its benefits such as cost savings, time savings, better quality and higher level of safety performance. Similarly, offsite construction has gained rapid growth as it helps to reduce the environmental impacts, e.g. dust and waste. However, there is lack of systematic review of environmental performance of off-site built facilities.

410 This study critically reviewed the literature related to off-site construction, especially in terms 411 of environmental performance. The review uncovered the mainstream studies on 412 environmental performance assessment of prefabricated buildings. Most existing studies chose to employ LCA method to systematically analyse carbon emissions and energy consumption of prefabricated residential buildings by using sub-assembly component as the

415 functional unit.

416 It was found that other environmental impacts (e.g. global warming, ozone exhausting and 417 water consumption) received less attention. Similarly, the existing body of knowledge mainly concentrated on manufacturing and construction stages of off-site built facilities. On the contrary, the operation and end-of-life stages were largely overlooked. The major challenge lies in the difficulty to acquire data in operation and end-of-life stages, especially real-time 
data. Indeed, system boundary and data accuracy present most significant challenges for the evaluation of environmental performance of off-site built facilities.

Based on the critical review of related literature, an agenda is developed for the future research in off-site built facilities (Fig.3). There are three directions of future research, i.e. sustainability rating system applied in OSC, IoT application in OSC monitoring, and an indicator system for the evaluation of OSC performance. These provide useful references for future studies in off-site construction.

\section{Acknowledgements}

The authors wish to express their sincere gratitude to the Natural Science Foundation of China (Grant No. 71801023) and Chongqing Science \& Technology Commission (No. cstc2018jcyjAX0099) for funding this research project. The authors would also like to acknowledge the support of Rising Star Fund by University of Brighton, and the SantanderUniversity of Brighton Undergraduate Research Scheme. Appreciation is also due to all members of the research team for their invaluable contributions.

\section{References}

[1] I.E. Agency, Tracking Clean Energy Progress: 2017, in, 2017.

439 [2] V.W. Tam, C.M. Tam, S. Zeng, W.C. Ng, Towards adoption of prefabrication in construction, 440 Building and environment, 42 (10) (2007) 3642-3654. [3] C. Mao, Q.P. Shen, W. Pan, K.H. Ye, Major Barriers to Off-Site Construction: The Developer's Perspective in China, Journal of Management in Engineering, 31 (3) (2015). construction in China: A cost-benefit analysis, Journal of Cleaner Production, 172 (2018) 649-660. [5] A.G.F. Gibb, Off-site fabrication: prefabrication, pre-assembly and modularisation, John Wiley \& Sons, Inc., 1999.

[6] R. Jiang, C. Mao, L. Hou, C.K. Wu, J.J. Tan, A SWOT analysis for promoting off-site construction under the backdrop of China's new urbanisation, Journal of Cleaner Production, 173 (2018) 225-234. [7] J. Hong, G.Q. Shen, Z. Li, B. Zhang, W. Zhang, Barriers to promoting prefabricated construction in China: A cost-benefit analysis, J. Clean Prod., 172 (Supplement C) (2018) 649-660.

[8] Z. Li, G.Q. Shen, X. Xue, Critical review of the research on the management of prefabricated construction, Habitat international, 43 (2014) 240-249.

[9] R.Y. Jin, S. Gao, A. Cheshmehzangi, E. Aboagye-Nimo, A holistic review of off-site construction literature published between 2008 and 2018, Journal of Cleaner Production, 202 (2018) 1202-1219. 

TO MODULAR OFFSITE CONSTRUCTION PRODUCTS, in: A. Maier, S. Skec, H. Kim, M. Kokkolaras, J. Oehmen, G. Fadel, F. Salustri, M. VanDerLoos (Eds.) Ds87-4 Proceedings of the 21st International Conference on Engineering Design, 2017, pp. 523-532.

459 [11] C.Z. Li, J. Hong, C. Fan, X. Xu, G.Q. Shen, Schedule delay analysis of prefabricated housing production: A hybrid dynamic approach, J. Clean Prod., (2017).

[12] C.Z. Li, J. Hong, F. Xue, G.Q. Shen, X. Xu, M.K. Mok, Schedule risks in prefabrication housing production in Hong Kong: a social network analysis, Journal of Cleaner Production, (2016).

[13] W. Pan, R. Sidwell, Demystifying the cost barriers to offsite construction in the UK, Construction Management and Economics, 29 (11) (2011) 1081-1099.

[14] W. Pan, A.G. Gibb, A.R. Dainty, Perspectives of UK housebuilders on the use of offsite modern methods of construction, Construction Management and Economics, 25 (2) (2007) 183-194.

[15] J. Molavi, D.L. Barral, A Construction Procurement Method to Achieve Sustainability in Modular Construction, Procedia Engineering, 145 (2016) 1362-1369.

[16] L. Jaillon, C.S. Poon, The evolution of prefabricated residential building systems in Hong Kong: A review of the public and the private sector, Automation in Construction, 18 (3) (2009) 239-248.

[17] V.W. Tam, I.W. Fung, M.C. Sing, S.O. Ogunlana, Best practice of prefabrication implementation in the Hong Kong public and private sectors, Journal of Cleaner Production, 109 (2015) 216-231. [18] X. Zhang, M. Skitmore, Y. Peng, Exploring the challenges to industrialized residential building in China, Habitat International, 41 (2014) 176-184.

[19] W. Pan, A.G. Gibb, A.R. Dainty, Strategies for integrating the use of off-site production technologies in house building, Journal of Construction Engineering and Management, 138 (11) (2012) 1331-1340.

[20] J. Wang, Z. Li, V.W. Tam, Critical factors in effective construction waste minimization at the design stage: a Shenzhen case study, China, Resources, Conservation and Recycling, 82 (2014) 1-7. [21] W. Lu, H. Yuan, Investigating waste reduction potential in the upstream processes of offshore prefabrication construction, Renewable and Sustainable Energy Reviews, 28 (2013) 804-811.

[22] J.J. Li, S. Lu, W.L. Wang, J. Huang, X.X. Chen, J.Y. Wang, Design and Climate-Responsiveness Performance Evaluation of an Integrated Envelope for Modular Prefabricated Buildings, Advances in Materials Science and Engineering, (2018).

[23] L. Ma, Y. Le, H.Y. Li, R.Y. Jin, P. Piroozfar, M.Q. Liu, Regional Comparisons of Contemporary Construction Industry Sustainable Concepts in the Chinese Context, Sustainability, 10 (11) (2018). [24] K. Nagy, E. Hajrizi, Beyond the Age of Oil and Gas - How artificial intelligence is transforming the energy portfolio of the societies, Ifac Papersonline, 51 (30) (2018) 308-310.

[25] Q. Wang, I. Martinac, The application of LCCA toward industrialized building retrofitting - Case studies of Swedish residential building stock, Smart Innovation, Systems and Technologies, (2013) 931-946.

[26] J.Y. Zhang, Y.T. Long, S.Q. Lv, Y.C. Xiang, BIM-enabled Modular and Industrialized Construction in China, in: O. Chong, K. Parrish, P. Tang, D. Grau, J. Chang (Eds.) Icsdec 2016 - Integrating Data Science, Construction and Sustainability, Vol. 145, 2016, pp. 1456-1461.

[27] R.Y. Jin, P.X.W. Zou, P. Piroozfar, H. Wood, Y. Yang, L.B. Yan, Y. Han, A science mapping approach based review of construction safety research, Safety Science, 113 (2019) 285-297. [28] J.B. Song, H.L. Zhang, W.L. Dong, A review of emerging trends in global PPP research: analysis and visualization, Scientometrics, 107 (3) (2016) 1111-1147.

[29] K. Krippendorff, Content Analysis: An Introduction to Its Methodology, SAGE Publications, 1980. [30] R.P. Weber, Basic Content Analysis, 2nd ed, Newbury Park, CA., 1990.

[31] U.S.G.A. Office, Content Analysis: A Methodology for Structuring and Analyzing Written Material, in, GAO/PEMD-10.3.1, Washington, D.C., 1996.

[32] S. Stemler, An overview of content analysis, Practical Assessment, Research \& Evaluation, 7 (17) (2001). 
[33] S.M. Bogus, G.C. Migliaccio, R.Y. Jin, Study of the Relationship between Procurement Duration and Project Performance in Design-Build Projects: Comparison between Water/Wastewater and Transportation Sectors, Journal of Management in Engineering, 29 (4) (2013) 382-391. [34] J. Jeong, T. Hong, C. Ji, J. Kim, M. Lee, K. Jeong, S. Lee, An integrated evaluation of productivity, Production, 142 (2017) 2393-2406.

[35] M. Kosir, N. Iglic, R. Kunic, Optimisation of heating, cooling and lighting energy performance of modular buildings in respect to location's climatic specifics, Renewable Energy, 129 (2018) 527-539. [36] Y. Teng, K.J. Li, W. Pan, T. Ng, Reducing building life cycle carbon emissions through prefabrication: Evidence from and gaps in empirical studies, Building and Environment, 132 (2018) 125-136.

[37] X.Y. Tao, C. Mao, F.Y. Xie, G.W. Liu, P.P. Xu, Greenhouse gas emission monitoring system for manufacturing prefabricated components, Automation in Construction, 93 (2018) 361-374. [38] G. Tumminia, F. Guarino, S. Longo, M. Ferraro, M. Cellura, V. Antonucci, Life cycle energy performances and environmental impacts of a prefabricated building module, Renewable \& Sustainable Energy Reviews, 92 (2018) 272-283.

[39] T.J. Wen, H.C. Siong, Z.Z. Noor, Assessment of embodied energy and global warming potential of building construction using life cycle analysis approach: Case studies of residential buildings in Iskandar Malaysia, Energy and Buildings, 93 (2015) 295-302.

[40] S. Lehmann, Low carbon construction systems using prefabricated engineered solid wood panels for urban infill to significantly reduce greenhouse gas emissions, Sustainable Cities and Society, 6 (2013) 57-67.

[41] G.W. Liu, T.Y. Gu, P.P. Xu, J.K. Hong, A. Shrestha, I. Martek, A production line-based carbon emission assessment model for prefabricated components in China, Journal of Cleaner Production, 209 (2019) 30-39.

[42] X.Y. Cao, X.D. Li, Y.M. Zhu, Z.H. Zhang, A comparative study of environmental performance between prefabricated and traditional residential buildings in China, Journal of Cleaner Production, 109 (2015) 131-143.

[43] J.S. Chou, K.C. Yeh, Life cycle carbon dioxide emissions simulation and environmental cost analysis for building construction, Journal of Cleaner Production, 101 (2015) 137-147.

[44] B.-G. Hwang, M. Shan, K.-Y. Looi, Key constraints and mitigation strategies for prefabricated prefinished volumetric construction, Journal of Cleaner Production, 183 (2018) 183-193.

[45] U.o. Brighton, Home for Christmas, in, <https://www.brighton.ac.uk/about-us/news-andevents/news/2017/12-20-home-for-christmas.aspx>, 2017.

[46] U.S.G.B. Council, LEED v4 for Building Design and Construction, in: D. Washington (Ed.), 2016. [47] I.E. Solutions, Integrated Environmental Solutions Virtual Environment (IES VE), in, $<$ https://www.iesve.com/>, 2019.

[48] WELL., WELL Certification., in, <https://www.wellcertified.com/>, 2019. [49] H. Zhu, J.K. Hong, G.Q. Shen, C. Mao, H.J. Zhang, Z.R. Li, The exploration of the life-cycle energy saving potential for using prefabrication in residential buildings in China, Energy and Buildings, 166 (2018) 561-570.

[50] Y.W. Kim, R. Azari-N, J.S. Yi, J. Bae, ENVIRONMENTAL IMPACTS COMPARISON BETWEEN ON-SITE VS. PREFABRICATED JUST-IN-TIME (PREFAB-JIT) REBAR SUPPLY IN CONSTRUCTION PROJECTS, Journal of Civil Engineering and Management, 19 (5) (2013) 647-655.

[51] L. Aye, T. Ngo, R.H. Crawford, R. Gammampila, P. Mendis, Life cycle greenhouse gas emissions and energy analysis of prefabricated reusable building modules, Energy and Buildings, 47 (2012) 159-168.

[52] J.K. Hong, G.Q. Shen, C. Mao, Z.D. Li, K.J. Li, Life-cycle energy analysis of prefabricated building components: an input-output-based hybrid model, Journal of Cleaner Production, 112 (2016) 21982207.

[53] B.G. Limited, BREEAM UK New Construction, in, 2018. 
[54] G.B.C.o. Australia, Green Star, in, <https://new.gbca.org.au/green-star/>, 2015.

[55] G.E. Marjaba, S.E. Chidiac, Sustainability and resiliency metrics for buildings - Critical review,

558 Building and Environment, 101 (2016) 116-125.

559 [56] M.R. Hosseini, I. Martek, E.K. Zavadskas, A.A. Aibinu, M. Arashpour, N. Chileshe, Critical

560 evaluation of off-site construction research: A Scientometric analysis, Automation in Construction,

56187 (2018) 235-247.

562 [57] W.X. Ding, X.Y. Jing, Z. Yan, L.T. Yang, A survey on data fusion in internet of things: Towards

563 secure and privacy-preserving fusion, Information Fusion, 51 (2019) 129-144.

564 [58] C. Mao, X. Tao, H. Yang, R. Chen, G. Liu, Real-Time Carbon Emissions Monitoring Tool for

565 Prefabricated Construction: An loT-Based System Framework, in: 2018 International Conference on

566 Construction and Real Estate Management: Sustainable Construction and Prefabrication, American

567 Society of Civil Engineers (ASCE), 2018, pp. 121-127.

568 [59] C.S. Tan, A. Nussbaumer, Structural feasibility of iso shipping containers for core-dwelling

569 housing, in: International Association for Bridge and Structural Engineering 2018, Kuala Lumpur,

570 2018, pp. 459-465.

571 [60] R.Y. Jin, H.P. Yuan, Q. Chen, Science mapping approach to assisting the review of construction and demolition waste management research published between 2009 and 2018, Resources Conservation and Recycling, 140 (2019) 175-188.

[61] W.S. Lu, Big data analytics to identify illegal construction waste dumping: A Hong Kong study, Resources Conservation and Recycling, 141 (2019) 264-272. [62] S.U.P. Abertawe, Chancellor of the Exchequer Announces $£ 36$ Million UK Funding for Swansea University Clean Energy Innovation, in, <http://specific.eu.com/chancellor-of-the-exchequerannounces-36-million-uk-funding-for-swansea-university-clean-energy-innovation/>, 2018. [63] A. GhaffarianHoseini, T.R. Zhang, O. Nwadigo, A. GhaffarianHoseini, N. Naismith, J. Tookey, K. Raahemifar, Application of nD BIM Integrated Knowledge-based Building Management System (BIM-

581 IKBMS) for inspecting post-construction energy efficiency, Renewable \& Sustainable Energy Reviews, 58272 (2017) 935-949.

583 [64] A. GhaffarianHoseini, T.R. Zhang, N. Naismith, A. GhaffarianHoseini, D.T. Doan, A.U. Rehman, O. 584 Nwadigo, J. Tookey, ND BIM-integrated knowledge-based building management: Inspecting postconstruction energy efficiency, Automation in Construction, 97 (2019) 13-28. 